特集：研究する動物園

第 14 回日本野生動物医学会大会シンポジウム 2008 年 9 月 3 日〜 7日

\title{
研究に協力する海獣たち
}

\author{
勝俣悦子 \\ 鴨川シーワールド = 296-0041 千葉県鴨川市東町 1464-18
}

\section{Captive Marine Mammals are Research Partners}

Etsuko KATSUMATA

Kamogawa Sea World, 1464-18 Higashicho, Kamogawa Chiba 296-0041, Japan

\begin{abstract}
The early research on cetaceans was developed from age determination by biological samples, such as growth layers in teeth, growth rings in ear plugs or reproductive organs collected by commercial whaling. Objects of research were shifted to the stranded or captive cetaceans after moratorium of commercial whaling.

Captive dolphins have contributed to not only exhibition but also study. The identifiable captive dolphins are more useful for observation and experiment for long terms. The results in research on reproductive biology captive animals can be applied to the wild. It is difficult to study cognitive science in wild and trained captive animals are also available.

Key words: captive marine mammals, research
\end{abstract}

\section{海獣類研究}

日本に抬ける鯨類の生物学的研究は, 最も関連の深い動物 学や水産学分野からではなく医学部の解剖学者である小川鼎三 によって昭和 7 年に，その形態学的研究と歯鯨の分類の基礎 が確立された [1]。小川鼎三は医学部の教授であるのになぜク ジラを研究するかについて,「ヒト山」と「クジラ山」のたと え話をしたと紹介している。哺乳類の世界にきわだって高い山 が扔互いに遠く離れたところにそびえたっている。それがヒ卜 山とクジラ山である。人間をよく理解するためには，時々クジ ラ山に登って，その頂からヒト山を眺めるのが良く，クジラを 理解することはヒトを理解するのに役立つという話であったと いう [2]。第二次世界大戦後, 大型のクジラに関しては捕鯨 操業によって得られた多くの試料を元に、再生産に関するさま ざまな生物学的特性值が明らかにされ，資源管理の基礎データ として広く利用された。しかし，大型鯨類の商業捕鯨が中止さ れた後には，座礁個体を用いた研究抽よび飼育鯨類を用いた非 捕殺的研究へと推移した。

わが国の水族館の歴史をさかのぼれば，初期のころは水族 館自体に研究能力がなくその自覚もない時代があった。「水族 館は研究材料を提供できる」という考えはあったが，水族館に は研究が必要で，その研究成果が水族館自身に還元されるべき という認識が内部から発せられたのは 1950 年後半になってか らであった [3]。動物園水族館協会からは，1959 年に動物園

Jpn. J.Zoo. WildI. Med. 14(1):33-35, 2009

水族館雑誌が発行され，研究発表の場が提供されている。この 雑誌は「ウンチの臭いがする」研究が特徴である。すなわち実 際に動物を报う飼育担当者が発信する研究成果であり, 飼育動 物から得られた貴重な報告といえる。

鴨川シーワールドの鳥羽山照夫元館長は，水族館が研究者 にとって単に試料提供の場であってはならないと力説し，国際 海洋生物研究所を設立して, 鯨類研究者と水族館の鯨類飼育者 の掛け橋となるシンポジウムを，1990 年〜2000 年に開催し た（図 1)。この努力により，水族館職員の研究に対する考え

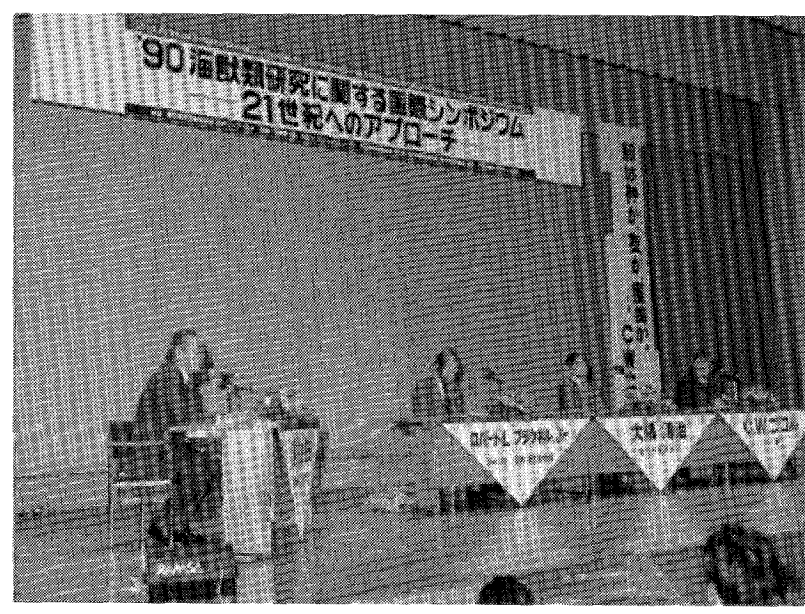

図 1 研究者と海獣類飼育園館が一同に会したシンポジウム 
方や，鯨類研究者の水族館に対する考え方が大きく変化した。 鰙脚類は丈夫で飼育しやすい動物でありカリフォルニアア シカ，ゴマフアザラシが多く飼育され，研究がなされている。 米国における獣医学的研究は 1960 年から 1970 年代に飼育動 物に関しての栄養, 血液学およで飼育や輸送などに関する研究 が行われ，鰙脚類研究の基礎が築かれた。Geraciによる栄養， 餌料 [4-7], Ridgwayによる海への適応に関する研究, 疾病, 麻酔 [8-10], Sweenyによる疾病, 感染症 [11-13] などの飼 育個体を用いた研究は，鯺脚類の獣医学の基礎となった。

\section{飼育動物の役割}

米国では研究機関や大学が専用の施設で研究を目的として 調教されたイルカを飼育しているが，日本にはそのような機関 がない。そこで，水族館の海獣がその役目を果たしている。飼 育動物は，水槽内で飼育され自らエサを探して捕食する必要が ないため，自然の行動をそのまま反映していると考えることは 危険である。しかし，識別された動物を使って長期間にわたる 実験や観察が可能であり, 自然界では困難な研究が行われ, 成 果を得ることができる。

特に繁殖に関わる行動は，種にとつて保守的であるこ とから飼育下で成果が期待できる。1971 年に発表された, Harrison and Ridgway [14] による論文が鯨類の繁殖生理学研 究の転機となった。彼らは，2 年間にわたりバンドウイルカに 関して同一個体の血中テストステロン濃度の変化を報告した。 同一個体に関する長期間にわたる調査を行った初めての例であ る。

野生からの搬入動物は, 飼育環境に適応するまでに 3 年を 必要とするが, 飼育が軌道にのり雌雄が健康であれば子どもが 生まれるようになる。飼育動物では受診動作を教えることで,

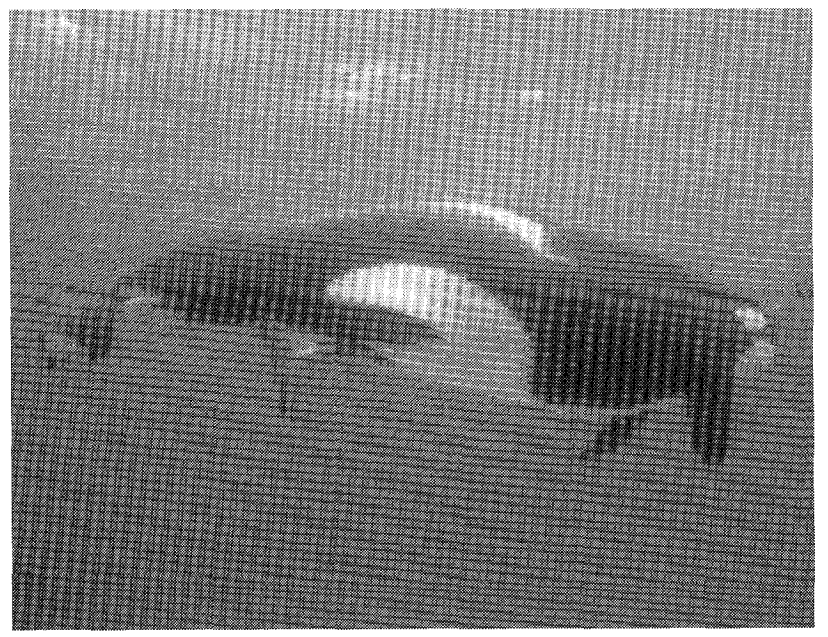

図 2 研究の成果は繁殖成功に結びつく
身体測定，採血，体温測定，水採取などを保定することなく 容易に行え, 成長, 性成熟過程のホルモン変動, その他につい て詳しく調査することが可能である。飼育下繁殖の成功は, 飼 育動物がプールという施設を「生活の場」と認めてくれたと判 断することができ, 飼育者としてはたいへんにうれしいことで ある。雄と雌の繁殖期の行動変化, 交尾の確認, その後の雌の 血液中ホルモン濃度変化や超音波診断によって妊娠診断をする ことができ, 出産に向けての準備がはじまる。野生シャチの研 究では妊娠期間は 15 か月とされていたが, 飼育下での出産例 からシャチの妊娠期間は 18 か月であることが明らかとなった (図 2)。このように野生状態での観察では明らかとすることが 難しい研究でも, 飼育することによって明らかとなる場合があ る。

また, 音響生態学的分野としては出生直後の子イルカの発 音開始時期や母親とのコミコニケーションの発音の発達過程な どを調べることができる。さらに感覚や認知の分野に関する研 究は，調教技術を駆使してこそ成り立つものである（図 3)。

これら飼育動物を用いた研究は, 研究者や他園館との共同, 独自の研究があるが, 水族館の職員の仕事は飼育・展示, 健康 管理が本来業務であり，研究は本職ではない場合が多い。よっ て, 研究者との共同研究がおおくなされている。飼育動物を用 いた研究は飼育に役立つ研究, 野生個体の保全に役立つ研究な どがあげられるが，研究のための研究はあってはならない。す なわち，共同研究を行う際には互いのメリットをよく検討すべ きであろう。

『日本の哺乳類学』を監修した大泰司紀之・三浦慎悟は, 次 のように述べている。

「私たちが取り組むべき哺乳類保全の課題とは, 保護活動, 保全計画，再生プログラムを実行するにとどまらず哺乳類の魅

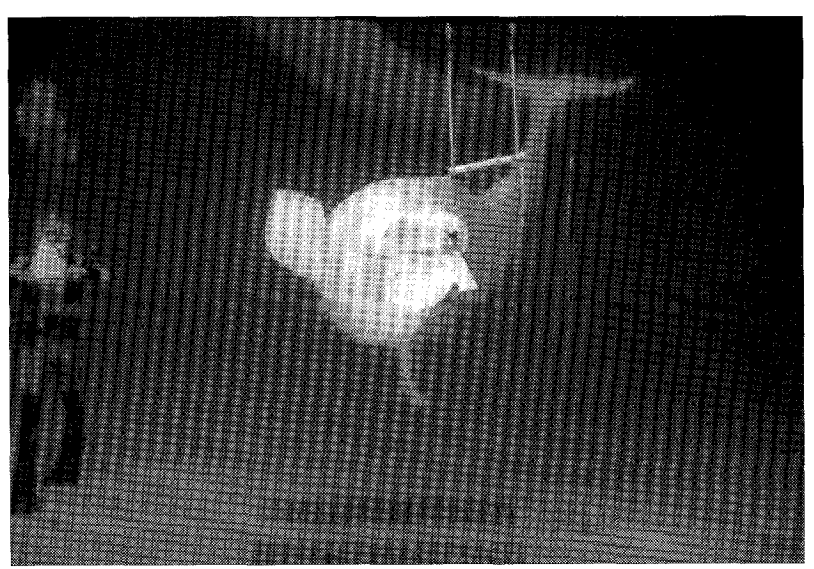

図 3 シロイルカを用いた認知に関する実験 成果はパフォーマンスとして一般公開されている 
研究に協力する海獣たち

力と面白さを存分に引き出し，人々に伝える努力も不可欠であ る。巧妙で興味深い形態や生物学的特性をメ力ニズムや機能と ともに明らかにする。(中略) そこに哺乳類とその生息環境を 保全する意義と重要性の源泉がある」 [15]。

ぜひとも飼育者が心に留めて扔きたい言葉である。

\section{要 約}

わが国における海獣類（鯨類）の研究は，捕鯨によって得 られた鯨の生殖腺および歯や耳垢による年齢查定から生物学的 な特性が明らかにされた。大型鯨類の商業捕鯨が全面禁止とな った後, 研究の対象は座礁・漂着した個体や飼育個体に移行し, 水族館で飼育・展示されているイル力は研究にも貢献している。

飼育下の海獣類では, 識別された個体を用いて長期にわた る実験や観察が可能である。繁殖に関する研究では，飼育下で の成果を自然界へフィードバックすることができる。調教技術 を用いた感覚や認知に関する実験や研究は, 自然界では困難な 研究であり，飼育下の海獣の活躍の場である。

キーワード：海獣類, 飼育, 研究

\section{引用文献}

1. 神谷敏郎. 1992. 鯨の自然誌. 中央公論社, 東京.

2. 大隅清治. 1988. 鯨は昔陸考歩いていた. PHP 研究所, 東京.

3. 鈴木克美, 西源二郎. 2005. 水族館学. 東海大学出版会. 秦野.

4. Geraci JR. 1972a. Experimental thiamine deficiency in captive harp seals, Phoca groenlandica, induced by eating herring, Clupea harengus, and smelts, Osmerus mordax. Can J Zool 50: 179-195.

5. Geraci JR. 1972b. Hyponatremia and the need for dietary salt supplementation in captive pinnipeds. J Am Vet Med Assoc: 161, 618-623.

6. Geraci JR. 1975. Pinniped nutrition. Rapp P-v Réun Cons Int Explor Mer 169: 312-323.

7. Harrison RJ, Ridgway SH. 1971. Gonadal activity in some bottlenosed dolphins, Tursiops truncatus. J Zool London 165: 355-366.

8. Ridgway SH, Simpson JG. 1969. Anesthesia and restraint for the California sea lion Zalophus californianus. Am Vet Med Assoc J 155: 1059-1063.

9. Ridgway SH. 1972. Homeostasis in the aquatic environment. In Mammals of the Sea (Ridgway SH ed.), pp.590-747. Charles C. Thomas, Springfield.

10. Ridgway SH, Geraci JR, Medway W. 1975. Diseases of Pinnipeds. Rapp P-v Réun Cons Int Explor Mer 169: 327-337.

11. Sweeney JC. 1973. Management of pinniped diseases. In Proc Am Assoc Zoo Vet pp.141-171.

12. Sweeney JC, Migaki G, Vainik PM, Conklin RH. 1976. Systemic mycoses in marine mammals. JAm Vet Med Assoc 169: 946-948.

13. Sweeney J. 1978. Infectious diseases of body systems. In Zoo and Wild Animal Medicine (Fowler ME ed.), pp.589-592. W.B. Saunders, Philadelphia.

14. Harrison RJ, Ridgway SH. 1971. Gonadal activity in some bottlenosed dolphins, Tursiops truncatus. J Zool London 165: 355-366.

15. 加藤秀弘. 2008. 日本の哺乳類学 3 水生哺乳類, 東京, 東京大学出版会. 